JOTE Volume 2 Nomor 1 Tahun 2020 Halaman 188-196 JOURNAL ON TEACHER EDUCATION

Research \& Learning in Faculty of Education

\title{
Meningkatkan Kemampuan Kognitif Dalam Mengenal Warna Melalui Bermain Media Penjepit Baju pada Anak Kb Adzkyah Bangkinang Kota secara BDR
}

\author{
Nurhalimah ${ }^{1}$, Dr. Nurmalina, M.Pd. ${ }^{2}$, Rizki Amalia, M.Pd. ${ }^{3}$ \\ S1 PG PAUD, Fakultas IImu Pendidikan, Universitas Pahlawan Tuanku \\ Tambusai Bangkinang. \\ Email: Halimah.nh53@gmail.com
}

\begin{abstract}
Abstrak
Penelitian ini bertujuan untuk meningkatkan kemampuan kognitif dalam mengenal warna melalui bermain media penjepit baju pada anak KB Adzkyah. Jenis penelitian yang digunakan adalah Penelitian Tindakan Kelas yang dilakukan secara kolaboratif antara peneliti dengan guru kelas. Penelitian ini terdiri dari dua siklus dan setiap siklusnya dilaksanakan 3 kali pertemuan. Subjek penelitian ini adalah 13 anak KB Adzkyah yang terdiri dari 8 anak laki-laki dan 5 anak perempuan. Objek penelitian adalah kemampuan kognitif dalam mengenal warna. Teknik pengumpulan data melalui observasi dan dokumentasi. Instrument yang digunakan adalah lembar observasi dan dokumentasi. Teknis analisis data dilakukan secara deskriptif kuantitatif. Hasil penelitian menunjukkan bahwa terdapat peningkatan kemampuan kognitif dalam mengenal warna. Hasil observasi pada pratindakan menunjukkan bahwa anak yang berkriteria berkembang sesuai harapan ada 2 orang atau 15,38\%. Pada siklus I meningkat menjadi 3 orang anak atau $23,07 \%$, dan pada siklus II meningkat lagi menjadi 8 orang anak atau $61,53 \%$.
\end{abstract}

Kata kunci: Kemampuan Kognitif, Mengenal Warna, Metode Bermain

\begin{abstract}
This study aims to improve cognitive abilities in recognizing colors through playing clothes clips in Adzkyah family planning children. The type of research used is Classroom Action Research which is conducted collaboratively between researchers and class teachers. This study consisted of two cycles and each cycle carried out 3 meetings. The subjects of this study were 13 Adzkyah family planning children consisting of 8 boys and 5 girls. The object of research is cognitive abilities in recognizing colors. Data collection techniques through observation and documentation. The instrument used was the observation sheet and documentation. The data analysis technique was done using quantitative descriptive method. The results showed that there was an increase in cognitive abilities in recognizing colors. The results of observations in the pre-action showed that children with criteria developed according to expectations, there were 2 people or $15.38 \%$. In the first cycle it increased to 3 children or $23.07 \%$, and in the second cycle it increased to 8 children or $61.53 \%$.
\end{abstract}

Keywords: Cognitive Ability, Recognizing Colors, Playing Methods 


\section{PENDAHULUAN}

Berdasarkan dari hasil pengamatan di KB Adzkyah Bangkinang Kota menunjukkan bahwa kemampuan kognitif anak dalam mengenal warna belum sesuai dengan pencapaian perkembangan anak usia 3-4 tahun. Peneliti membuktikan dari hasil pengamatan pada tanggal 17 Maret 2020, dari 13 anak di kelas hanya terdapat 2 anak yang mencapai kemampuan mengenal warna yang sesuai dengan tingkat pencapaian perkembangan anak usia 3-4 tahun yang terdapat pada Permendikbud Nomor 137 tahun 2014. Peneliti menemukan pada saat kegiatan mengenalkan warna masih ada beberapa anak yang belum benar dalam menyebutkan warna apa yang ditunjuk oleh guru, dan ada anak yang hanya bisa menyebutkan satu warna untuk semua warna yang ditunjukan oleh guru. Hal tersebut disebabkan proses dalam mengenal warna oleh guru lebih cenderung memberikan nama-nama warna dan menunjukkan warna dengan metode ceramah. Kurangnya variasi metode pembelajaran dalam kegiatan pembelajaran mengakibatkan perkembangan kognitif anak kurang terlatih, anak hanya menerima informasi dan kurangnya pemberian kesempatan kepada anak untuk memiliki pengalaman langsung melalui permainan sederhana.

Salah satu aspek penting dalam perkembangan kognitif anak yaitu kemampuan mengenal suatu objek termasuk dalam mengenal warna. Bukan hanya mengenal saja, namun anak juga harus memahami warna-warna yang ada di sekitarnya. Mengenal warna akan membantu anak untuk dapat menyebutkan warna, mampu menyampaikan hasil karya mereka dan merekapun akan mampu mengelompokkan warna. Pengenalan warna untuk anak usia 3-4 tahun yaitu berada pada mengenal 5-7 macam warna (Permendikbud Nomor 137 Tahun 2014). Kemampuan warna harus disesuaikan dengan perkembangan anak usia dini.

Kognitif atau intelektual adalah suatu proses berfikir berupa kemampuan atau daya untuk menghubungkan suatu peristiwa dengan peristiwa lainnya serta kemampuan menilai dan mempertimbangkan segala sesuatu yang diamati dari dunia sekitar. Kognitif dapat diartikan sebagai pengetahuan yang luas daya nalar, kreatifitas atau daya cipta, kemampuan berbahasa serta daya ingat. Gabungan antara kemampuan anak dengan pengaruh lingkungan disebut kognisi. Dalam kognisi anak dapat menyelesaikan masalah lingkungan sendiri (Khadijah, 2016).

Piaget (Suryana, 2016) mengemukakan, "semua anak memiliki pola perkembangan kognitif yang sama yaitu melalui empat tahapan, diantaranya : 
sensori-motor, pra-operasional, operasional-konkrit, dan operasional-formal. Keempat tahap perkembangan tersebut berlaku serentak disemua aspek perkembangan kognitif. Perkembangan kognitif anak usia 3-4 tahun berada pada tahap pra-operasional yaitu anak mulai menunjukkan proses berpikir yang lebih jelas. Anak mulai mengenali beberapa simbol dan tanda termasuk bahasa dan gambar. Anak menunjukkan kemampuannya melakukan permainan simbolis. Penguasaan bahasa anak pada tahap pra-operasional sudah sistemastis, anak sudah mampu melakukan permainan simbolis, imitasi, serta mampu mengantisipasi keadaan yang akan terjadi pada waktu mendatang".

Kemampuan kognitif diperlukan oleh anak dalam rangka mengembangkan pengetahuannya tentang apa yang mereka lihat, dengar, rasa, raba atau pun cium melalui panca indera yang dimilikinya. Kognitif berhubungan dengan intelegensi, kognitif lebih bersifat pasif atau statis yang merupakan potensi atau daya untuk memahami sesuatu, sedangkan intelegensi lebih bersifat aktif yang merupakan aktualisasi atau perwujudan dari daya atau potensi tersebut yang berupa aktivitas atau perilaku. Kognitif adalah suatu proses berpikir, yaitu kemampuan individu untuk menghubungkan, menilai dan mempertimbangkan suatu kejadian atau peristiwa ( Sujiono, 2014).

Peran guru dalam menstimulasi anak mengenalkan warna sangat dibutuhkan. Pengenalan warna dapat dilakukan oleh guru dengan memilih kegiatan yang menarik, sederhana, menyenangkan bagi anak dan tentunya dapat mengembangkan kemampuan kognitif anak dalam mengenal warna. Melatih anak melalui kegiatan dan menggunakan berbagai media tersebut dapat menstimulasi kemampuan dalam mengenal warna baik kemampuan menunjuk, menyebutkan dan mengelompokan warna. Peran orang tua dalam mengembangkan kemampuan kognitif anak sangat besar. Anak-anak tidak bisa hidup sendirian tanpa adanya bantuan dari orangtua mereka. Maka, dengan adanya peran dari orang tua, mereka bisa berkreasi dan mengembangkan keterampilan. Oleh karena itu peran orang tua sangat menentukan keberhasilan anak dimasa mendatang.

Usaha anak mengenal warna dapat dikembangkan dan ditingkatkan dalam kegiatan pembelajaran melalui bermain penjepit baju, anak dapat mengenal jenis warna yang terdapat dalam gambar dan penjepit baju yang digunakan dalam permainan penjepit baju tersebut. Menurut Parlina (2017), "bermain penjepit baju adalah suatu aktifitas yang menimbulkan kesenangan bagi anak dengan menggunakan alat bantu permainan berupa penjepit baju, sehingga mereka 
dapat mengenal warna dari macam-macam warna yang terdapat pada penjepit baju". Bermain merupakan kebutuhan anak yang harus ia penuhi. Oleh karena itu, salah satu prinsip pembelajaran Pendidikan Anak Usia Dini adalah belajar melalui bermain (Fauziddin, 2017: 6).

Bermain merupakan suatu kegiatan yang dilakukan dengan atau tanpa mempergunakan alat, yang menghasilkan pengertian dan memberikan informasi, memberikan kesenangan maupun mengembangkan imajinasi anak. Jika kita benar-benar memahaminya maka pemahaman tersebut akan berdampak positif pada cara kita membantu proses belajar anak. Bermain merupakan aktivitas yang paling disukai oleh semua anak (Triharso, 2013).

Permainan adalah cara utama anak untuk terlibat secara aktif dengan lingkungannya dan untuk berpikir dan belajar. Permainan memberikan kesempatan praktik dan berfikir, sehingga anak bisa mendapat pengalaman dan belajar lewat semua jenis materi. Kegiatan yang ada dalam permainan mendorong kemampuan alami anak untuk belajar dengan mengizinkan mereka untuk menyentuh, menjelajahi, merasakan, menguji, melakukan percobaan, berbicara, dan berpikir (Morisson, 2012).

\section{METODE}

Metode penelitian yang digunakan oleh peneliti dalam penelitian ini adalah metode penelitian tindakan kelas (PTK) yang bersifat kolaboratif dan partisipatif dengan melibatkan mahasiswa sebagai peneliti dan guru kelas KB Adzkyah sebagai kolaborator sekaligus pengajar. Penelitian ini bertujuan untuk meningkatkan kemampuan dalam mengenal warna melalui bermain media penjepit baju pada anak KB Adzkyah Bangkinang Kota secara BDR.

Penelitian tindakan kelas ini rencananya akan dilaksanakan di KB Adzkyah, Jalan Kartini Kecamatan Bangkinang Kota Kabupaten Kampar untuk mengamati kemampuan anak mengenal warna secara BDR. Penelitian ini akan dilaksanakan pada pertengahan semester dua tahun ajaran 2019-2020. Penentuan waktu penelitian mengacu pada kalender akademik sekolah, karena PTK memerlukan beberapa siklus yang membutuhkan proses belajar mengajar yang efektif di kelas. PTK ini direncanakan akan dilaksanakan melalui dua siklus untuk melihat peningkatan hasil belajar dan aktivitas anak dalam mengikuti proses pembelajaran mengenal warna di sekolah melalui metode bermain penjepit baju.

Penelitian ini menggunakan bagan alur penelitian Arikunto. S.dkk (2014). Penelitian ini direncanakan akan dilaksanakan dalam dua siklus yaitu siklus I dan 
siklus II. Setiap siklus terdiri dari empat tahapan yaitu perencanaan (planning), tindakan (acting), pengamatan (observing), dan refleksi (reflecting) dan seterusnya. Dalam penelitian ini aspek yang dikembangkan adalah kemampuan kognitif dalam mengenal warna melalui metode bermain media penjepit baju. Salah satu cara mengatasi permasalahan tersebut adalah dengan menyusun perencanaan belajar mengajar yang baik. Untuk memecahkan masalah, peneliti membuat rencana baru yang mendorong tercapainya tujuan yang diharapkan. Subjek penelitian dalam penelitian tindakan kelas ini adalah anak KB Adzkyah Bangkinang Kota yang berjumlah 13 anak, terdiri dari 8 anak laki-laki dan 5 anak perempuan.

Teknik pengumpulan data yang dilakukan dalam penelitian ini adalah observasi. Observasi digunakan untuk mengamati tingkat kemampuan mengenal warna. Selain itu, observasi dilakukan untuk mengamati atau pengambilan data guna melihat seberapa jauh akibat dari tindakan yang telah diterapkan berdasarkan pada panduan yang telah dipersiapkan dalam lembar observasi. Kegiatan observasi melibatkan dua orang yaitu peneliti dibantu oleh teman sejawat.

\section{PEMBAHASAN}

\section{Pratindakan dan Siklus I}

Berdasarkan hasil penelitian yang telah dilakukan dapat diketahui anak yang belum berkembang pada pratindakan 7 orang anak $(53,84 \%)$, sedangkan pada siklus I tidak ada. Dengan terjadinya penurunan dari persentase tersebut disebabkan karena anak telah mampu mengenal warna meskipun dengan bimbingan. Penilaian anak dalam kategori mulai berkembang pada pratindakan berjumlah 4 orang anak (30,76\%), sedangkan pada siklus I berjumlah 10 orang anak $(76,92 \%)$, hal ini disebabkan karena anak telah bersemangat dalam mengenal warna meskipun anak masih diingatkan.

Penilaian anak dalam kategori berkembang sesuai harapan pada pratindakan berjumlah 2 orang anak (15,38\%), sedangkan pada siklus I berjumlah 3 orang anak (23,07\%). Terjadinya kenaikan ini karena anak telah mampu melakukan kegiatan bermain dengan media penjepit baju dan mampu mengenal warna tanpa dibimbing lagi. Selain itu, penilaian anak berkembang sangat baik pada pratindakan maupun siklus I belum ada. 


\section{Siklus I dan Siklus II}

Hasil penelitian pada siklus I dan siklus II menunjukkan bahwa adanya peningkatan kemampuan mengenal warna pada anak KB Adzkyah Bangkinang Kota. Berdasarkan hasil penelitian yang dilakukan pada siklus I penilaian anak dalam kategori belum berkembang sudah tidak ada, begitu juga pada siklus II. Penilaian anak dalam kategori mulai berkembang pada siklus I berjumlah 10 orang anak (76,92\%), sedangkan pada siklus II berjumlah 2 orang anak $(15,38 \%)$, hal ini disebabkan karena perkembangan anak dalam mengenal warna sudah mulai lebih baik. Penilaian anak dalam kategori berkembang sesuai harapan pada siklus I berjumlah 3 orang anak (23,07\%), sedangkan pada siklus II meningkat menjadi 8 orang anak $(61,53 \%)$.

Penilaian anak dalam kategori berkembang sangat baik pada siklus I belum ada, sedangkan pada siklus II mengalami peningkatan menjadi 3 orang anak $(23,07 \%)$. Hal ini disebabkan karena anak telah mampu mengenal dan mendeskripsikan warna-warna yang telah dikenalkan kepada anak selama bermain dengan media penjepit baju secara BDR.

Berikut ini persentase kemampuan mengenal warna melalui bermain media penjepi baju secara BDR mulai tahap pratindakan sampai siklus II:

Tabel Persentase Hasil Penilaian Aktivitas Anak

\begin{tabular}{|c|c|c|c|c|c|c|c|c|}
\hline \multirow[t]{2}{*}{$\begin{array}{l}\text { Taha } \\
\text { p }\end{array}$} & \multicolumn{2}{|c|}{$\begin{array}{c}\text { Belum } \\
\text { Berkemban } \\
\mathbf{g}\end{array}$} & \multicolumn{2}{|c|}{$\begin{array}{c}\text { Mulai } \\
\text { Berkemban } \\
\mathbf{g}\end{array}$} & \multicolumn{2}{|c|}{$\begin{array}{c}\text { Berkemban } \\
\text { g Sesuai } \\
\text { Harapan }\end{array}$} & \multicolumn{2}{|c|}{$\begin{array}{l}\text { Berkemban } \\
\text { g Sangat } \\
\text { Baik }\end{array}$} \\
\hline & $\mathbf{F}$ & $\%$ & $\mathbf{F}$ & $\%$ & $\mathbf{F}$ & $\%$ & $F$ & $\%$ \\
\hline $\begin{array}{l}\text { Pratindaka } \\
\text { n }\end{array}$ & 7 & 53,84 & 4 & 30,76 & 2 & 15,38 & 0 & 0 \\
\hline Siklus I & 0 & 0 & 10 & 76,92 & 3 & 23,07 & 0 & 0 \\
\hline Siklus II & 0 & 0 & 2 & 15,38 & 8 & 61,53 & 3 & 23,07 \\
\hline
\end{tabular}


Untuk lebih jelasnya dapat dilihat pada gambar berikut ini:

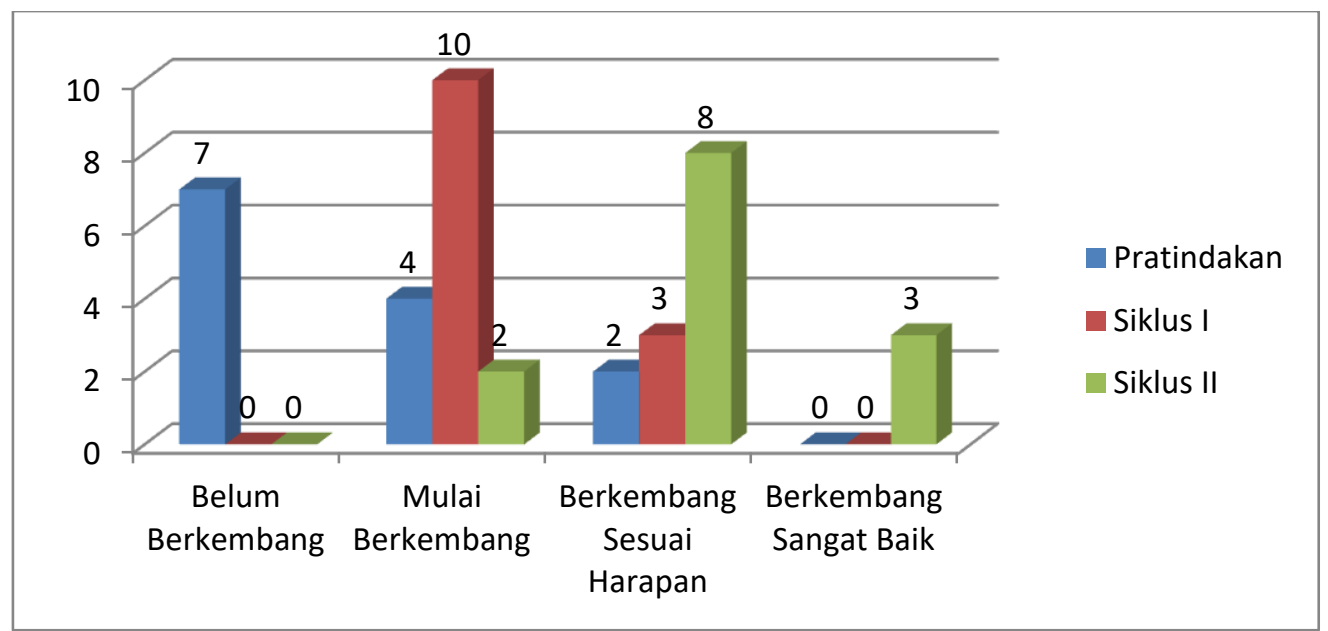

Gambar Perbandingan Pratindakan, Siklus I, dan Siklus II

Setelah melihat hasil data kemampuan anak KB Adzkyah Bangkinang Kota dalam mengenal warna pada grafik di atas dapat diketahui bahwa bermain dengan media penjepit baju dapat meningkatkan kemampuan mengenal warna. Hal ini dapat dilihat dari meningkatnya grafik persentase kemampuan mengenal warna pada anak usia 3-4 tahun setelah melakukan kegiatan bermain dengan media penjepit baju.

Hasil observasi dan penelitian pada siklus I terlihat anak sudah lebih menyukai kegiatan pembelajaran dan mengikutinya dengan antusias yang lebih tinggi. Kegiatan pembelajaran yang digunakan adalah melalui metode bermain dengan media penjepit baju yang tentunya aman bagi anak. Metode pembelajaran ini sangat mudah dilakukan oleh anak usia 3-4 tahun, dan kegiatan bermain ini sangat menyenangkan bagi anak.

Pada prinsipnya pembelajaran di PAUD tidak terlepas dari kegiatan bermain yang menyenangkan. Namun, dalam pelaksanaan tindakan siklus I masih kurang kondusif. Pada siklus II, anak menjadi antusias dan terlibat aktif dalam mengenal warna melalui bermain dengan media penjepit baju secara BDR. Hal ini dikarenakan dengan pemberian reward kepada anak yang mau melakukan. Dengan melakukan permainan ini anak semakin bersemangat untuk belajar, karena pada dasarnya anak sangat menyukai praktek dari pada teori. Oleh karena itu, kemampuan mengenal warna pada anak KB Adzkyah Bangkinang Kota sudah meningkat. 


\section{KESIMPULAN}

Berdasarkan hasil penelitian dan pembahasan, maka dapat disimpulkan bahwa kemampuan kognitif dalam mengenal warna melalui bermain media penjepit baju pada anak KB Adzkyah Bangkinang Kota secara BDR, pada semester genap tahun pelajaran 2019-2020 dapat ditingkatkan melalui metode bermain sederhana. Metode pembelajaran dilakukan dengan cara menjepitkan kartu-kartu gambar yang berwarna ke media penjepit baju. Peningkatan kemampuan kognitif dalam mengenal warna dapat dilihat dari adanya peningkatan persentase dari tahap pratindakan dan setelah dilakukan tindakan.

Hasil observasi pada tahap pratindakan, anak yang berkembang sesuai harapan 2 orang anak atau 15,38\%. Kemampuan anak dalam mengenal warna pada siklus I yang berkembang sesuai harapan meningkat menjadi 3 orang anak atau $23,07 \%$. Pada siklus II kemampuan anak berkembang sesuai harapan mencapai 8 orang anak atau $61,53 \%$ dan pada siklus II ini kemampuan anak yang berkembang sangat baik mencapai 3 orang anak atau 23,07\% dari jumlah keseluruhan anak yaitu 13 orang anak.

\section{DAFTAR PUSTAKA}

Arikunto, Suharsimi, dkk. (2014). Penelitian Tindakan Kelas. Jakarta: PT Bumi Aksara.

Fauziddin. (2017). Pembelajaran PAUD Bermain, Cerita, dan Menyanyi Secara Islami. Bandung: PT Remaja Rosdakarya.

Kementerian Pendidikan Dan Kebudayaan, Peraturan Menteri Kependidikan Dan Kebudayaan Republik Indonesia Nomor137 tahun 2013 Tentang standar Nasional Pendidikan Anak Usia Dini. Jakarta : Kementrian Pendidikan Dan Kebudayaan.

Kementerian Pendidikan Dan Kebudayaan, Peraturan Menteri Kependidikan Dan Kebudayaan Republik Indonesia Nomor 146 tahun 2014 Tentang Kurikulum 2013 Pendidikan Anak Usia Dini. Jakarta : Kementrian Pendidikan Dan Kebudayaan.

Khadijah. (2016). Pengembangan Kognitif Anak Usia Dini. Medan: Perdana Publishing.

Morisson. (2012). Dasar-Dasar Pendidikan Anak Usia Dini (PAUD). Jakarta: PT Indeks.

Sujiono, dkk. (2014). Metode Pengembangan Kognitif. Jakarta : Universitas Terbuka.

Suryana. (2016). Stimulasi \& Aspek Perkembangan Anak. Jakarta: PT. Remaja Rosdakarya. 
Triharso. (2013). Permainan Kreatif \& Edukatif untuk Anak Usia Dini. Yogyakarta: CV. Andi Offset

Parlina. (2017), Meningkatkan Kemampuan Kognitif Anak dalam Mengenal Warna Melalui Bermain Penjepit Baju Pada Anak Kelompok A PAUD AlHasanah Jambi. Tersedia dalam http://repository.fkip.unja.ac.id/search/detil/Meningkatkan Kemampuan Kognitif Anak dalam Mengenal Warna Melalui Bermain Penjepit Baju Pada Anak Kelompok A PAUD Al-Hasanah Jambi.html [diakses 17 Maret 2020] 